\title{
Environmental, Social and Governance Disclosures: A Call for Integrated Reporting in Nigeria
}

\author{
Adebimpe Otu Umoren ${ }^{1, *}$, Ekubiat John Udo ${ }^{2}$, Bokime Sunday George ${ }^{1}$ \\ ${ }^{1}$ Department of Accounting, Faculty of Business Administration, University of Uyo, Akwa Ibom State, Nigeria \\ ${ }^{2}$ Department of Accountancy, Akwa Ibom State Polytechnic, Ikot Osurua, Ikot Ekpene, Nigeria
}

\section{Email address:}

bimpeumoren@yahoo.com (A. O. Umoren),ekujohn@yahoo.com (E. J. Udo), bokimegeorge@gmail.com (B. S. George)

\section{To cite this article:}

Adebimpe Otu Umoren, Ekubiat John Udo, Bokime Sunday George. Environmental, Social and Governance Disclosures: A Call for Integrated Reporting in Nigeria. Journal of Finance and Accounting. Vol. 3, No. 6, 2015, pp. 227-233. doi: 10.11648/j.jfa.20150306.19

\begin{abstract}
Annual reports of most companies quoted on the Nigerian Stock Exchange (NSE) have been found to be deficient, because they lack vital financial and non-financial information that would enable stakeholders make informed decisions. The aim of this study was to investigate the environmental, social and governance (ESG) practices of Nigerian quoted companies and discuss the need for integrated reporting (IR). A checklist was developed to capture the ESG disclosures from the annual reports of 40 companies listed on the Nigerian Stock Exchange over a two-year period from 2013 to 2014 . The ESG determinants were proxied by company size, profitability and auditor type. Company size was measured by total assets, profitability was measured by return on equity (ROE), and auditor type was measured by a dummy variable, ' 1 ' for Big 4 and ' 0 ' for otherwise. The data obtained were analysed using descriptive statistics, correlation and regression. The findings revealed that, the level of ESG disclosure was 53\%, this was made up environmental scores (7\%), social scores (66\%) and governance scores $(81 \%)$. This showed that governance information was the most disclosed while environmental information was the least disclosed. Findings also revealed that ESG disclosure practice was influenced by auditor type; but not by company size and profitability. The current trend of integrated reporting worldwide calls for Nigerian companies to be proactive. There is a need to improve on ESG practices by integrating the financial and ESG elements to generate a single integrated report, which allows both the company and its stakeholders to make better-informed decisions.
\end{abstract}

Keywords: Environmental, Social and Governance (ESG) Disclosures, Annual Reports, ESG Determinants, Integrated Reporting

\section{Introduction}

Annual reports are required to furnish all stakeholders with financial and non-financial information, which is relevant, faithfully represented and useful for making prudent, effective and efficient decisions. Both financial and nonfinancial information disclosures have now become an area of interest for stakeholders. Hence, the need for every organisation to disclose in their annual reports the various activities that affect the stakeholders. This practice is becoming a very fundamental issue the world over.

In the past, emphasis was on the financial elements of the annual reports prepared on the basis of Generally Acceptable Accounting Principles (GAAP), and this was considered to be a model for reporting. Over the years, financial statements have gradually grown increasingly voluminous and complex due to ever-increasing accounting standards and disclosure requirements. Financial reporting is often criticized for its focus on historic, quantitative and short-term performance, rather than on long-term value creation. Corporate reporting based only on accounting standards allows companies to externalise environmental and social costs due to the fact that financial results are not placed within the context of the greater economy, society or the environment in which the business operates [1]. According to [2] traditional corporate reports are increasingly less relevant and useful for analysts and investors as they are difficult for even the most sophisticated users to understand.

[3] opined that users of financial information today, need the data that would allow them to assess whether the entity is environmentally, socially and financially responsible. It is expected that businesses should do more than simply turn in financial statements in line with the accounting standards. They are expected to operate in a manner that is socially and 
ethically responsible as well as minimise negative impacts on the environment. They should also contribute positively to the community where they operate by taking into consideration the varied needs of their stakeholders.

According to [4], information provided under corporate responsibility reporting has become incoherent as it fails to provide a clear link between economic drivers, financial information, as well as social and environmental impacts of corporate strategies. Currently, in most jurisdictions around the world, the minimum requirement is the inclusion of significant non-financial information in company reporting. Many organizations have increased the pace of corporate disclosures but, key information gaps remained. In the wave of heightened expectations of corporate transparency and accountability, greater requirement is being placed in the pursuit of accounting for the interrelationship between environmental, social and governance (ESG), as well as financial performance and business strategy.

Even in the midst of the IFRS adoption controversies in developing countries, there is a new move towards integrated reporting, a more comprehensive model that encompasses significant elements of traditional reporting and environmental, social and governance reporting within a single presentation [5]; of course, and firms have been put under increasing pressure from a variety of stakeholders to integrate social and environmental considerations into their operations and to ensure higher standards of governance. Only few countries have mandated the use of integrated reporting, but, there have been evidence of voluntary participation worldwide. The largest companies in Denmark are now obliged to report on non-financial information while South Africa has made significant progress in addressing the challenges of Integrated Reporting (IR) by mandating all listed entities to issue annual integrated reports instead of annual financial and sustainability reports.

[3] examined annual reporting of companies in Nigeria using cross sectional survey design. Findings revealed that no listed company in Nigeria reported under the integrated framework. The level of environmental, social and governance (ESG) practices of Nigerian quoted companies after the adoption of IFRS is yet to be determined. From the empirical studies of United States of America and Japan [6] Australia [7], and Saudi Arabia [8], it has been established that company's specific attributes such as company size, profitability and auditor type influence environmental, social and governance disclosures. In Nigeria however, it appears there is no study yet that has identify the factors that influence environmental, social and governance disclosures.

Against this background, the aim of this study was to;

1. Determine the level of environmental, social and governance (ESG) practices of Nigerian quoted companies after the adoption of IFRS.

2. Identify the determinants of ESG disclosure practices in Nigeria.

3. Discuss the need for Nigerian companies to embrace integrated reporting.

The Null hypothesis $\left(\mathrm{H}_{\mathrm{o}}\right)$ was formulated to guide the study:
$H_{o}$ : Companies' attributes (company size, profitability and auditor type) do not influence ESG disclosure practices in Nigeria.

The remainder of the paper is organized as follows: in the second section, the review of relevant literature on the subject is addressed. The details on the research methods adopted for the study are presented in section three while in the fourth section, the results and discussions are disclosed. Ultimately, the summary, conclusion and recommendations based on findings are addressed in section five.

\section{Review of Relevant Literature}

\subsection{Theoretical Perspective}

A number of different theories provide a sound foundation to substantiate ESG disclosures. Examples are: the Legitimacy theory [9]; [10], [11]; Stakeholder theory [12]; Political economy theory [13] and Social political theory [14]. However, the most cited theoretical perspective in the ESG accounting literature explaining corporate motivations for reporting is based on legitimacy theory [12], [11]. Legitimacy is a generalised perception or assumption that the actions of an entity are desirable, proper, or appropriate within some socially constructed system of norms, values, beliefs, and definitions [10]. Legitimacy theory, according to [9] and [10] is value system-centred. Legitimacy exists at the organisational level when there is congruence between organisation and society value system. This study is guided by legitimacy theory, a system-oriented theory that views companies as part of a broader social system within which they operate. Organisational Legitimacy Theory suggests that a firm may be in one of four phases with regard to its legitimacy. These phases are establishing, maintaining, extending and defending legitimacy [15]. Establishing legitimacy represents the early stages of a firm's development and tends to revolve around issues of competence. Maintaining legitimacy is the phase that most firms would generally expect to be operating in, where their activities include ongoing role performance and symbolic assurances that all is well, and attempts to anticipate and prevent or forestall potential challenges to legitimacy. Extending legitimacy is a point where an organisation enters new markets or changes the way it relates to its current market. Defending legitimacy may be threatened by an incident (internal or external), and therefore require defence. In summary, the theo-----retical terms suggest that a political economy theory of ecological, social and governance are both viable and may contribute toward our understanding of observed developments in national reporting practices.

\subsection{Nature and Scope of Environmental Accounting, Social Accounting, Corporate Governance and Integrated Reporting}

Environmental accounting covers information relating to all aspects of the environment - related expenditure, environmental benefits of products and details regarding sustainable operations. It is an inclusive field of accounting 
that provides reports for both internal use, generating environmental information to help make management decisions on pricing, controlling overhead and capital budgeting, and external use, disclosing environmental information of interest to the public and to the financial community [16].

Social accounting is a rational assessment of and reporting on some meaningful domain of business organisations activities that have social impact. [17] defined social accounting as the preparation and publication of an account about an organisation's social, environmental, employee, community, customer and other stakeholder interactions and activities and, where, possible the consequences of those interactions and activities.

Corporate governance refers to procedures and processes according to which an organisation is directed and controlled. It provides the structure through which the objectives of the company are set, and the means of attaining those objectives and monitoring performance are determined [18].

Environmental, social and governance (ESG) refers to the three main areas of concern that have developed as central factors in measuring the sustainability and ethical impact of an investment in a company or business. ESG is the catch-all term for the criteria used in what has become known as socially responsible investing. Socially responsible investing is among several related concepts and approaches that influence and, in some cases govern how asset managers invest portfolios [19].

Regarding Integrated reporting (IR), although there is no generally acceptable definition, the International Integrated Reporting Council (IIRC) describes integrated reporting as something that "brings together material information about an organization's strategy, governance, performance and prospects in a way that reflects the commercial, social, and environmental context within which it operates". The concept of IR is a blend of two essential backgrounds of corporate disclosures; specifically, financial reporting and sustainability reporting. With financial reporting, the firm serves as a connection of the relationship amongst direct stakeholders whose primary responsibilities include the maximization of shareholders wealth. While sustainability reporting broaden the concept of IR, it is premised on the notion that the firm is a community made up of interdependent stakeholders bound together through a value-creation process, with a commitment to long-term equitable value creation [3].

The main objective of IR is to achieve the convergence of reporting architecture that builds upon the assimilation of knowledge, issues and metrics flowing from the enthusiasm of the society and economic dynamics. To achieve this objective financial reporting and sustainability reporting must be integrated. Thus, IR will affect all stakeholders in the following ways:

i. IR will reflect and communicate the full value creation process within the organization.

ii. IR will integrate all capitals along organization's full value chain.

iii.IR will offer principle-based approach for greater focus on unique factors in clear understandable language.

iv. IR will provide greater transparency covering broader range of issues, disclosing the positive with the negative and helping to build superior trust.

$\mathrm{v}$. IR is future oriented, responsive, concise, reliable and thus, promote consolidation of reporting practices.

\subsection{Prior Studies on the Determinants of ESG Disclosures}

[20] examined the determinants of corporate non-financial disclosures practices of Spanish firms using annual reports of 41 Spanish firms for the year 2007. Findings revealed that there is positive relationship between firm size, profitability, auditor type and level of corporate social and environmental disclosure practices as suggested by many authors cited by him [11]. He qualified this positive relationship between firm size and profitability and the level of disclosures to be valid only in the case of environmentally sensitive industries. However, findings in the study by [21] have not supported any association between firm size and the social disclosures made by the firm in the case of Spain. These findings in the study by [21] have not been supported by any other study. [22] examined the impact of corporate attributes on environmental disclosure among quoted firms in Nigeria. The researchers investigated a sample of one hundred randomly selected firms quoted on the Nigerian Stock Exchange. Data were extracted from the financial statements of the companies and Nigerian Stock Exchange Factbook. The data were analyzed using descriptive statistics, and Binary probit regression analysis. It was observed that performance of the firm (profitability) and the industry type had a significant influence on environmental disclosure. Separate studies also discussed under the following headings:

Company size and ESG disclosures: Advocates of stakeholder theory state that larger companies come under more scrutiny than smaller companies, thus they feel the pressure to disclose more environmental, social and corporate governance information to obtain approval from the stakeholders for continued survival. Larger firms are also perceived to be important economic entities and therefore have greater demands placed on them to provide more information for customers, suppliers, analysts and government bodies. A positive association between size of a corporation and the amount of environmental disclosure has been consistently found by prior studies such as [21, 23, 6, 8]. [24] However, found a negative relationship between the size of the company and the level of CSR disclosure.

Profitability and ESG disclosures: [25] argued that management of profitable organisations may disclose detailed information in the annual report because they feel comfortable communicating this good news to the stock market in order to improve the firms' valuation. However mixed empirical results were found in both emerging and developed countries. For instance, [25, 24 and 26] provided results which support a profit-environmental, social and governance reporting relationship. [24] provided evidence for a positive relationship between lagged profit and non-financial disclosure. [12] and [27] found no association between amount 
of disclosure and profitability. [27] concluded that both size of the organisation and industry are significantly associated with amount of disclosure, whilst profitability is not. It is consistent with other studies as neither [28] nor [29] could find evidence of a relationship between environmental disclosure and profitability for New Zealand companies. Separate studies also revealed the determinants of environmental, social and corporate governance.

Auditor type and ESG disclosures: The primary responsibility for preparing the annual report lies with company management; external auditors play a major role in the disclosure policies and practices of their clients. [25] argued that big auditors exert a monitoring role in limiting the opportunistic behaviour by management. [30] suggested that large audit firms have a greater incentive to report. If the client issues inadequate disclosure, this is likely to diminish the reputation of large audit firms more than small audit firms, which causes large audit firms to be more diligent. Previous research suggested that auditing firms that belong to the Big 4, Big 5 or Big $6(\operatorname{Big} N)$ are more sophisticated or have better audit quality [31] than non-Big $\mathrm{N}$ auditing firms. Higher quality auditor may help clients prepare more sophisticated annual reports with advanced financial and non-financial information, including environmental disclosures.

\section{Methodology}

Ex-post facto research design was adopted. This design was deployed as it permitted the examination of independent variables in retrospect for their possible relationship with dependent variables. The population for this study consisted of 188 quoted companies on the Nigerian Stock Exchange. Taro Yamane's Statistical Formula was used to select sample size of 40 out 188 quoted companies. Purposive sampling technique was used to select the samples. It was adopted based on the ease with which the data could be collected from companies' website as at July, 2015. Data in this study were derived from 40 quoted companies from 8 sectors listed on the Nigerian Stock Exchange covering the period from 2013 to 2014, being the most recent annual reports available online. These sectors were Consumer Goods (9), Conglomerates (2), Construction (2), Healthcare (4), ICT (2), Industrial Goods (9), Oil and Gas (5) and Services (7). Data were obtain from the online published annual reports of the select companies, specifically from the Directors' report, Corporate Governance Report, Statement of Financial Position, Statement of Comprehensive Income, and Notes to the Financial Statements. In order to determine the level of ESG disclosures, a checklist of 30 questions was developed by the researchers in line with previous studies [27] and [32] to capture the environmental, social and governance information using content analysis. Each company was scored " 1 " for full or partial disclosure and " 0 " for nondisclosure. The disclosure score $\left(\mathrm{DS}_{\mathrm{i}}\right.$ ) for each company was computed by using the formula below;

$\mathrm{DS}_{\mathrm{i},}=\sum(\mathrm{ESG}$ information disclosed $) / \sum$ (all possible ESG disclosures)
The data obtained was analyzed using descriptive statistics, correlation and linear regression.

This model was used:

$$
\mathrm{DS}_{\mathrm{it}}=\alpha_{0}+\beta_{1} \mathrm{TA}_{i, t}+\beta_{2} \mathrm{ROE}_{\mathrm{i}, \mathrm{t}}+\beta_{3} \mathrm{AT}_{\mathrm{i}, \mathrm{t}}+\varepsilon_{\mathrm{i}, \mathrm{t}}
$$

Where:

$i, t$ is for company $i$ in year $t$,

$\alpha$ is the intercept

$\beta$ is the coefficient of the independent variables

$\varepsilon$ is the error term

The definitions of the dependent and independent variables and their expected signs are as given on the table below.

Table 1. Dependent and Independent Variables.

\begin{tabular}{|c|c|c|c|}
\hline Variables & Types & Definition & $\begin{array}{l}\text { Expected sign } \\
\text { for independent } \\
\text { variables }\end{array}$ \\
\hline $\begin{array}{l}\text { Disclosure } \\
\text { Score }\end{array}$ & Dependent & $\begin{array}{l}\text { Environmental } \\
\text { Disclosure (DSE) } \\
\text { Social Disclosure } \\
\text { (DSS) Governance } \\
\text { Disclosure (DSG) } \\
\text { Environmental, Social } \\
\text { and Governance } \\
\text { Disclosure Score (DS) } \\
\text { DS= DSE+DSS+DSG }\end{array}$ & \\
\hline $\begin{array}{l}\text { Company } \\
\text { size }\end{array}$ & Independent & $\begin{array}{l}\text { Total Assets of the } \\
\text { companies (TA). }\end{array}$ & Positive \\
\hline Profitability & Independent & $\begin{array}{l}\text { (ROE) i.e the ratio of } \\
\text { Profit for the year to } \\
\text { Equity }\end{array}$ & Positive \\
\hline $\begin{array}{l}\text { Auditor } \\
\text { Type }\end{array}$ & Independent & $\begin{array}{l}\text { Auditor Type (AT); } 1 \\
\text { for Big “ } 4 \text { ", } 0 \text { for } \\
\text { otherwise. }\end{array}$ & Positive \\
\hline
\end{tabular}

\section{Data analysis and findings}

\subsection{Descriptive Statistics}

Table 2 shows the descriptive statistics of the variables. It depicts the number of observations (N), minimum, maximum, mean and standard deviation of the variables used.

Table 2. Descriptive Statistics of Dependent and Independent variables.

\begin{tabular}{llllll}
\hline & N & Minimum & Maximum & Mean & $\begin{array}{l}\text { Std. } \\
\text { Deviation }\end{array}$ \\
\hline DSE & 80 & .00 & .50 & .0700 & .13063 \\
DSS & 80 & .20 & .90 & .6600 & .12985 \\
DSG & 80 & .00 & 1.00 & .8113 & .17860 \\
DS & 80 & .13 & .73 & .5256 & .09894 \\
TA & 80 & 68087621.00 & $9.85 \mathrm{E} 11$ & $7.9802 \mathrm{E} 10$ & $1.60719 \mathrm{E} 11$ \\
ROE & 80 & -18.26 & 164.57 & 17.8580 & 24.12842 \\
AT & 80 & .00 & 1.00 & .6500 & .47998 \\
Valid N & 80 & & & & \\
(listwise) & & & & & \\
\hline
\end{tabular}

Table 2 shows that average disclosure score is .5256 with a range from a maximum of .73 to a minimum of .13 and with 
a standard deviation of .09894 . This suggests a very low variation on the disclosure score of the quoted companies over the period of observation. Specifically, the average environmental, social and governance scores were $7 \%, 66 \%$ and $81 \%$ respectively. This shows that governance information was the most disclosed while environmental information was the least disclosed. The total assets reveal a mean of 7.9802E10, a minimum of 68087621, a maximum of $9.85 \mathrm{E} 11$. The return on equity reveals an average of $17.85 \%$. The range is from -18.26 to 164.57 with a standard deviation of 24.126. This shows that Nigerian quoted companies are profitable. The auditor type shows an average of $65 \%$, minimum of 0 and maximum of 1 and standard deviation of .48. This shows that $65 \%$ of the sampled quoted companies use the Big 4 as their auditors.

\subsection{Discussion of Findings}

Table 3. Correlation Matrix.

\begin{tabular}{lllll}
\hline & DS & TA & ROE & AT \\
\hline DS & 1 & 0.139 & 0.119 & $0.338^{*}$ \\
TA & 0.139 & 1 & 0.163 & 0.144 \\
ROE & 0.119 & 0.163 & 1 & $0.221^{*}$ \\
AT & $0.338^{*}$ & 0.144 & $0.221^{*}$ & 1 \\
\hline
\end{tabular}

Correlation is significant at the 0.05 level (2 - tailed).

Correlation is used to test the presence of multicollinearity among the variables. The result is as depicted on Table 3. It reveals that correlation between disclosure score and total assets, return on equity, and auditor type are $0.139,0.119$ and 0.338 respectively. The correlation between total assets and return on equity is 0.163 , between total assets and auditor type is 0.144 , and between auditor type and return on equity is 0.221 . This shows that the correlation is not high between each of the variables.

The potential effect of multicollinearity on the regression is also assessed by using the Tolerance level and Variance Inflation Factor (VIF). Tolerance level is above 0.2 (0.961, $0.934,0.939)$ and VIF did not exceed 10 (1.040, 1.071, $1.065)$, this reveals that multicollinearity is not a challenge. The normal P-P plot of regression standardized residual suggests no major deviations from normality. The DurbinWatson checks the serial correlation, the result is about 2 (2.037), which shows that regression model has a good fit.

Table 4. Regression Result.

\begin{tabular}{llll}
\hline \multirow{2}{*}{ Variables } & \multicolumn{2}{l}{ Model } & \\
\cline { 2 - 4 } & Coefficients $^{\mathbf{a}}$ & t-values & Significance \\
\hline (Constant) & & 25.516 & .000 \\
Total assets & .087 & 0.796 & .758 \\
Return on equity & .034 & 0.310 & .005 \\
Auditor Type & .318 & 2.866 & .428 \\
& R square & 0.124 & \\
& Adj R square & 0.089 & \\
& F value & 3.570 & \\
& Sig & 0.018 & \\
& DW & 2.037 & \\
\hline
\end{tabular}

Table 4 is used in presenting the regression result. The beta coefficients show the contribution of each independent variable. The beta coefficient for company size is 0.087 , for profitability is 0.034 and for auditor type is 0.318 . The largest beta is for auditor type, this means it is the variable that makes the strongest contribution in explaining the ESG disclosure practices.

The results also show that $\mathrm{t}$-calculated for company size, profitability and auditor type are $0.796,0.310$ and 2.866 respectively. The critical value at $10 \%$ level of significance is 1.664. The t-calculated for both the company size and profitability is less than the critical value; hence the null hypothesis is retained at $10 \%$ sig. level. This result deviates from the researchers' point of view, that ESG disclosure is influenced by company size and profitability. The result supports the study of [24] and contradicts the studies of [11].

The t- calculated for auditor type exceeds the critical value; hence the null hypothesis is rejected at $10 \%$ sig. level. This result is a confirmation that ESG disclosure is influenced by auditor type, which is in line with the researcher's expectation. The result supports the studies of [25], [20] and [31].

The $\mathrm{R}$ square indicates how much of the variance in the ESG disclosure scores are explained by the model. The result shows R squared of .124, which means the model, explains 12 percent of the variance in ESG disclosure practices. However, from the ANOVA result, the F value (3.570) which tests the regression relationship between the independent and dependent variable is significant.

\subsection{A Call for Nigerian Companies to Embrace Integrated Reporting}

Evidence-based studies that collectively examined environmental, social and governance disclosure practices (integrated reporting) in developing nations are scarce, especially in Nigeria. This may be due to the voluntary practices across nations. International Integrated Reporting Council, [33] opined that annual reports are already protracted and are getting lengthier yet they remain separate, disconnected strands as critical interdependencies exist among the essential variables. [3] examined annual reporting of companies in Nigeria using cross sectional survey design. Findings revealed that no listed company in Nigeria reported under the integrated framework and concluded that potential benefits await all economic agents. These benefits include total reflection and communicate of the full value creation process within the organization; integration of all capitals along organizations full value chain; can provide greater transparency covering broader range of issues disclosing the positive with the negative and helping to build superior trust and offer principle-based approach for greater focus on unique factors in clear and understandable language. The study concluded that IR would lead to increased trust, confidence and reputation of firms and the country as a whole. [32] investigated companies' environmental, social, governance (ESG), and financial implications of their commitment to the United Nations Global Compact (UNGC). The database search provided a 
total of 198 companies operating in Spain, France, and Japan that were committed to the UNGC. These companies were monitored from 2008 - 2013, grouped in 10 primary economic sectors in the Global Industry Classification Standard (GICS) system. The results clearly revealed that adoption of the UNGC often requires an organizational change that fosters stakeholders' engagement, ultimately resulting in improvements in companies' ESG performance. Additionally, the results indicate that ESG performance has a significant impact on financial performance for companies that adopted the principles of the UNGC both non-financial and financial incentives to foster sustainable businesses and community development. [34] assessed whether ESG ratings were related to firm performance.

Through a multivariate analysis, it was confirmed of the differences between the ESG scores used to evaluate environmental, social and corporate governance factors of rated companies. They found that selected US companies in the bottom 25\% (Worst In Class, termed WIC) of their industries according to ESG scores perform significantly better than those in the top 25\%, (Best In Class, termed BIC). Also, that BIC companies have significant higher revenue per employee and cash flow per share compared the industry medians. Attending to these results, it seems that extreme strategies on ESG issues produced better economic results than those strategies that are in line with the industry. [35] examined the impact that environmental, social and governance (ESG) corporate practice disclosure has on equity financing. They observed that corporate non-financial ESG performance disclosure impacts firm valuation and investment decision. Thus, investors react more to bad ESG practices disclosure than to good ESG ones.

There are many benefits of exploring integrated reporting. Key among them are (i) improved internal information, allowing management to make better resource allocation decisions leading to potential cost reductions and (ii) more concise, less complex reporting. Pilot program companies report seeing extensive changes in thought processes across their organizations, and are using the integrated reporting concepts to drive their focus on integrated thinking and strategic decision-making. As companies consider an integrated approach to reporting, their traditional performance reporting may reflect varying degrees of integration and different approaches to communicating data. Some companies have produced non-public integrated reports, which have enabled them to test systems and processes internally. Others have incorporated integrated reporting concepts into their annual reports.

Corporate reporting will continue to evolve with the changing business environment and stakeholder expectations. Adding integrated reporting to management's agenda and to board strategy sessions may help companies determine how to meet these evolving expectations. The integrated reporting concepts may provide companies with a useful framework when considering how to best disclose environmental, social, and governance matters that they have decided to report. Companies may also improve their access to capital and achieve strategic business benefits from integrated thinking [35].

\section{Conclusion}

The environmental, social and governance (ESG) practices of Nigerian quoted companies and their determinants were examined in this study. The finding reveals that, the level of ESG disclosure is $53 \%$, this is made up environmental scores (7\%), social scores $(66 \%)$ and governance scores $(81 \%)$. This shows that governance information is the most disclosed while environmental information is the least disclosed. It is the conclusion in this study, that ESG disclosure practice is influenced by auditor type; but not by company size and profitability. There is a need to improve on ESG practices by integrating the financial and ESG elements to generate a single integrated report, which allows both the company and its stakeholders to make better-informed decisions.

\section{Recommendations}

The following recommendations are made:

1. The Big 4 should be the trailblazers on integrated reporting. They should train their Nigerian field staff and clients on how to prepare integrated reports. They should educate their clients on the likely benefits of implementing integrated reporting and advise them to prepare annual integrated reports.

2. Nigerian Financial Reporting Council (FRC) should partner with professional bodies, academics and other regulatory authorities in Nigeria towards developing an acceptable integrated reporting framework that will increase transparency and accountability in corporate reporting.

3. The implication of this paper is a formal call for the regulatory authorities to support and institute integrated reporting (IR) in Nigeria.

\section{References}

[1] G. Terry, "Why corporate leaders need to embrace sustainability to ensure future profitability". The South African Institute of Chartered Accountants: Kengray, South Africa. 2008.

[2] R. Eccles and M. Krzus, One report: integrated reporting for a sustainable strategy. New Jersey: John Wiley \& Sons, Inc. "Ethics" (2010). vol. 49, pp. 143-165.

[3] M. Oladipupo, G. Mathias and A. Mohammed,. Integrated reporting: another crisis of external dependence or a model for sustainable capital allocation? European Journal of Globalization and Development Research, 2013, vol. 8 (1), pp. 492-506.

[4] PwC Integrated reporting: the future of corporate reporting. Retrieved September 08, 2015 from http://pwc.de/integratedreporting.html. 2012. 
[5] KPMG International survey of corporate responsibility reporting. KPMG International Cooperative, 2011.

[6] L. Ho, and M. E. Taylor, "An empirical analysis of triple bottom line reporting and its determinants: Evidence from the United States and Japan. Journal of International Management and Accounting, 2007, vol. 18(2).

[7] E. Eltaib, "Environmental accounting disclosures of Australian oil and gas companies". Research Online University of Wollongong Thesis Collections; 2012, pp. 1281.

[8] W. Albassam, "Corporate governance, voluntary disclosure and financial performance: ban empirical analysis of Saudi listed firms using a mixed-methods research design", PhD thesis. http://theses.gla.ac.uk/5280/2014.

[9] C. K. Lindblom, "The implications of organizational legitimacy for corporate social performance and disclosure", Critical Perspectives on Accounting Conference, New York, 1994.

[10] M. C. Suchman, M. C, "Managing legitimacy: strategic and institutional approaches". Academy of Management Journal, 1995, vol. 20, No. 3, pp. 571-610.

[11] C. Deegan, M. Rankin, and P. Voght, Firms' disclosure reactions to major social incidents: Australian evidence, Accounting Forum, 2000, vol. 24 (1), pp. 101-130.

[12] R. Gray, R. Kouhy, and S. Lavers, "Corporate social and environmental reporting: a review of the literature and a longitudinal study of UK disclosure", Accounting, Auditing \& Accountability Journal, 1995, vol. 8 (2), pp. 47-77.

[13] S. Williams, "Voluntary environmental and social accounting disclosure practice in the Asia-Pacific Region: an international empirical test of political economy theory", The International Journal of Accounting, 1999, vol. 34, pp. 209-238.

[14] C. Huang, and F. Kung, "Drivers of environmental disclosure and stakeholder expectation: evidence from Taiwan", Journal of Business Ethics, 2010, vol. 96, pp. 435-451.

[15] K. M, Hearit, "Mistakes were made': organizations, apologia, and crises of social legitimacy", Communication Studies, 1995, vol.46 (1-2), pp. 1-17. http://www.oecd.org/dataoecd/32/18/31557724.pdf.

[16] V. Dorweiler, and M. Yakhou, "Environmental accounting: An essential component of business strategy". Business Strategy and the Environment; 2004, vol.13, pp. 65-77.

[17] Gray, R. H. (2000). The social accounting project and accounting, organisations and society: Privileging engagement, imaginings, new accountings and pragmatism over critique? Accounting, Organisations and Society, 27, 687-708.

[18] OECD Principles of Corporate Governance, 2004, p. 11,

[19] Lemke \& Lin, Regulation of Investment Advisers, Thomson West, 2014, vol. 2, p. 158.

[20] J. Echave and S. Bhati, "Determinants of social and environmental disclosures by Spanish Companies". GSMI Third Annual International Business Conference, Michigan, USA: Global Strategic Management., 2010, pp. 55-68.

[21] J. Prado-Lorenzo, M. I. Gallego-Alvarez, M. I. and M. GarciaSanchez, "Stakeholder engagement and corporate social responsibility reporting: the ownership structure effect". Corporate Social-Responsibility and Environmental Management, 2009, vol. 16(2), p. 94.

[22] N. Osazuwa, O. Francis, and F. Izedonmi, "Corporate attributes and environmental disclosures of Nigerian quoted firms: an empirical analysis". Research Journal of Social Science \& Management, 2013, vol. 3, (6), pp. 150-158.

[23] E. Stammy, and K. Ely, "Corporate environmental disclosures about the effects of climate change". Corporate SocialResponsibility and Environmental Management, 2008, vol. 15(6), pp. 338-352.

[24] R. W. Roberts, "Determinant of corporate social responsibility disclosure: an application of stakeholder theory". Accounting Organisations and Society, 1992, vol.17 (6), pp. 595-612.

[25] A. Ali, C. Durtschi, B. Lev, and M. Trombley, M. "Changes in institutional ownership and subsequent earnings announcement abnormal returns". Journal of Accounting, Auditing and Finance, 2004, vol. 19, pp. 221-48.

[26] S. Stanwick, and P. Stanwick,. Corporate social responsiveness: An empirical examination using the environment. International Journal of Commerce \& Management, ABI/INFORM Global, 1998.

[27] D. Hackston, and M. Milne, Some determinants of social and environmental disclosures in New Zealand companies. Accounting, Auditing and Accountability Journal, 1996, vol. 9 (1), pp. $77-108$.

[28] H. Davey, "Measuring corporate environmental performance: The trade-offs of sustainability ratings". Business Strategy and the Environment, 1982, vol. 19, pp. 245-260.

[29] A. Ng, "Corporate social disclosure: a note on a test of agency theory". British Accounting Review, 1985, vol. 23 (3), pp. 211-218.

[30] E. Fama, and M. Jensen, "Separation of ownership and control". Journal of Law and Economics, 1983, vol. 25, 301325 .

[31] P. Gupta, and N. Nayar, "Information content of control deficiency disclosures under the Sarbanes-Oxley Act: An empirical investigation". International Journal of Disclosure and Governance, 2007, Vol. 4(1), 3-24.

[32] E. Ortas, I. Álvarez, and A. Garayar, "The environmental, social, governance, and financial performance effects on companies that adopt the United Nations global compact". Journal Sustainability, 2015, vol. 7, pp. 1932-1956; doi: 10.3390/su7021932.

[33] IIRC, Discussion paper on towards integrated reporting communicating value in the $21^{\text {st }}$ century, 2013, Retrieved September 08, 2015 from http://www.the iirc.org.html.

[34] A. Peiró-Signes, M. Segarra-Oña, J. Mondéjar-Jiménez, and Vargas-Vargas, M. Influence of the environmental, social and corporate governance ratings on the economic performance of companies: an overview. International Journal of Environmental Research, 2013, vol. 7(1) pp. 105-112.

[35] P. Crifo, V. Forget, and S. Teyssier, The price of environmental, social and governance practice disclosure: an experiment with professional private equity investors. Journal of Corporate Finance, 2015, 30, pp. 168-194. 